\title{
Executive Creep in Canadian Provincial Legislatures
}

\author{
Paul E.J. Thomas ${ }^{1 \star}$ and J.P. Lewis ${ }^{2}$ \\ ${ }^{1}$ Carleton University, Room B640 Loeb Building, 1125 Colonel By Drive, Ottawa ON, K1S 5B6 and \\ ${ }^{2}$ University of New Brunswick - Saint John, 100 Tucker Park Rd., PO Box 5050, Saint John NB, E2L 4L5 \\ ${ }^{*}$ Corresponding author. Email: paul.thomas@carleton.ca
}

\begin{abstract}
Studies of parliamentary systems contend that backbench legislators are increasingly marginalized, with power being centralized in the executive. However, such research typically focuses on national legislatures, ignoring subnational jurisdictions. We extend this literature by exploring the process of "executive creep" in Canada's provinces; namely the tendency of executives to erode legislative independence by appointing backbenchers to quasi-executive positions or cabinet committees. We examine executive creep in all provinces since 1968, finding a clear trend towards the increased incorporation of backbenchers into the work of the executive. Moreover, these changes serve to strengthen the power of first ministers relative to their cabinets.
\end{abstract}

\section{Résumé}

Les études sur les systèmes parlementaires soutiennent que les législateurs d'arrière-ban sont de plus en plus marginalisés, le pouvoir étant centralisé au sein de l'exécutif. Cependant, ces recherches se concentrent généralement sur les législatures nationales, sans tenir compte des ordres de gouvernement infranationaux. Nous élargissons l'étude de la question en explorant le processus de "dérive de l'exécutif » dans les provinces canadiennes, c'est-à-dire la tendance des autorités exécutives à éroder l'indépendance législative en nommant des députés d'arrière-ban à des postes quasi exécutifs ou à des comités du Cabinet. Nous examinons la dérive de l'exécutif dans toutes les provinces depuis 1968, et nous constatons une nette tendance vers l'intégration accrue des députés d'arrière-ban dans le travail de l'exécutif. De plus, ces évolutions servent à renforcer le pouvoir des premiers ministres par rapport à leur cabinet.

\section{Introduction}

As of May 2017, there were few more endangered political species than backbench government members of the Legislative Assembly of Ontario. ${ }^{1}$ Just two of the 57 members of the governing Liberal party sat as private members without also serving in a cabinet, junior ministerial, whip, or some other quasi-executive position. Aside 
from the Speaker and one other member, all Liberal legislators also sat on one of the provincial cabinet committees that develop the government's new policy and legislative initiatives. Given the comparatively small size of Canada's provincial legislatures, a decrease in the private members available for scrutiny, or the co-optation of members into the work of the government, threatens the proper functioning of responsible government (Docherty, 2005; Thomas and White, 2015). Moreover, this trend is compounded by recent reductions in the number of seats in several provincial assemblies, which leaves fewer private members to begin with.

Those studying parliamentary systems have long voiced concerns over the increasing centralization of power in the hands of the executive and the threat this poses to legislative authority (for example, Franks, 1987; Ostrogorsky, 1902; Poguntke and Webb, 2005; Weller, 1985; Wheare, 1963). In recent years such anxieties have reached a fever pitch within Canada (see Aucoin et al., 2011; Loat and MacMillan, 2015; Page, 2015; Russell and Sossin, 2009; Savoie, 1999), although in Canada, as in other parliamentary systems, debate remains as to whether power is concentrated within the cabinet as a whole or specifically in the hands of the Prime Minister.

To date, however, most of the research examining the centralization of power has focused on national level political systems, with subnational or devolved administrations being largely ignored. As several observers lament, this research also typically relies on anecdote rather than systematically documenting shifts in the structure or operation of political institutions either over time or between jurisdictions (for example, Cooper, 2017; Elgie, 2011; White, 2012).

We seek to fill these gaps by examining whether the relationships between government legislators and the executives in Canada's provinces have changed in ways that undermine the independence of the former and concentrate power in the hands of the latter. Building on expectations derived from the literature on party discipline, we explore two dimensions of what we identify as the process of "executive creep," which we define as the increasing incorporation of government backbenchers into the work of the executive. First, we track the size of the executive in every province from 1968 to 2017, examining not only the size of cabinet but also the growth in quasi-executive roles, such as whips, caucus chairs, house leaders and especially junior executive positions similar to the parliamentary secretaries at the Canadian federal parliament. Second, we examine the inclusion of backbench members on cabinet committees, documenting the spread of the practice and its current uptake.

While variations exist across jurisdictions, the results show a clear trend towards the increased incorporation of government backbenchers into the work of the executive, with every Canadian province now having either a system of parliamentary secretaries, the involvement of backbenchers on some form of ministerial committees or both. Moreover, we demonstrate that this reduction in backbencher autonomy has occurred in ways that strengthen the power of first ministers relative to their cabinets. Examining changes in the executive roles and responsibilities provided to government backbenchers can therefore help us better understand the phenomenon of centralization and its implications for the broader relationship between executives and legislatures. Our results also contribute to the few studies 
that seek to provide empirical verification for the centralization thesis, particularly at the provincial level (Bernier et al., 2005; Cooper, 2017).

The paper proceeds as follows. The first section reviews the debate over the centralization of power in the hands of executives and first ministers, mapping its contours at both the federal and provincial levels. Next, we draw on the literature on party discipline to develop expectations for how the process of centralization would change the executive's relationship to government legislators. We then present our analytical approach and methods before examining the results.

\section{The Centralization Debate in Canadian Politics}

Students of Westminster legislatures have long been concerned with the growing concentration of power in the hands of first ministers, a trend Cooper (2017) refers to as the "centralization thesis." Proponents of this concept hold that political power was first drawn away from parliament to an increasingly institutionalized cabinet and then progressively from the cabinet to the prime minister and a small "court" of powerful advisers (Dowding, 2013; Elgie, 2011; Rhodes, 1995; Savoie, 1999). This centralization is seen to undermine the checks that the cabinet, bureaucracy and legislature are supposed to provide on executive power. In particular, centralization is seen to strengthen party discipline and weaken legislative capacity, leading to a lack of accountability and responsiveness (Aucoin et al., 2011). However, some question whether the prime minister is truly as powerful as the centralization thesis suggests (Bakvis, 2001; Lewis, 2013; Thomas, 2003; White, 2005). Others also dispute the era and actors identified by the centralization thesis, arguing that prime ministers have always wielded immense power, with little change over time (Dutil, 2017).

Research on provincial governance largely replicates the federal debates. On one side are those who contend that "provincial government is cabinet government" (Dunn, 2016: 315). Those in this school argue that premiers are the most powerful political figure in each province but still operate as part of the cabinet team (Dunn, 2016). On the other side are those who contend that "provincial government is premier's government" (Young and Morley, 1983:54). Canada's history is littered with premiers who dominated politics in their respective provinces, such as W.A.C. Bennett (British Columbia), Ernest Manning (Alberta), Leslie Frost (Ontario), Maurice Duplessis (Quebec) or Joey Smallwood (Newfoundland and Labrador). In the modern era, the premier-dominant view is perhaps most clearly articulated by White, who-despite his doubts about the centralization thesis at the federal level-argues that "premiers have the capacity to dominate both their cabinets and their entire governments to a far greater extent than does the Prime Minister" (2005: 55; see also Atkinson et al., 2013; Dyck, 1996).

Settling the conflict between the cabinet- and premier-dominated camps is challenging given the limited empirical evidence available, although both major studies to date favour the latter. Utilizing case studies from each jurisdiction, Bernier and colleagues (2005) found that premiers' control over their cabinets varied with institutional factors, such as the presence of central agencies, as well as shorter-term factors including their public popularity and caucus support. They also report that the centralization of power in the premier and weakening of the legislature is facilitated 
by cabinet growth, which typically requires a structured, committee-based system that first ministers can more easily control. More recently, Cooper (2017) reviewed all deputy ministerial appointments across all provinces between 1920 and 2013 . He demonstrates that while in the past deputy minister reassignments primarily occurred after changes in governing party, since 1980 such shuffles have also occurred following the selection of a new premier from the same party. Cooper concludes that power has been centralized to the premiers, who reassign deputy ministers to encourage personal rather than partisan loyalty.

\section{Centralization and the Marginalization of Provincial Legislatures}

Parliamentary systems feature a fusion of the executive and legislative branches, with the first minister and cabinet being drawn from the members of the legislature. Nonetheless, a key principle of the Westminster system is that the government is responsible to the legislature for the conduct of its affairs and only remains in power so long so long as it maintains the confidence of elected members. This means that all legislators who are not part of the executive-including government backbenchers-theoretically have the duty to hold the government to account for its actions and to withdraw their confidence should it fail to meet their expectations.

Practice, however, is different from theory. Executives looking to maintain themselves in office have increasingly sought to reverse the confidence relationship by finding ways to control backbench government legislators. As a result, the scrutiny function is now almost exclusively performed by those representing opposition parties, and governments whose parties control the majority of legislative seats need not worry about losing the confidence of the legislature.

Concerns over the marginalization of private members in provincial legislatures are well established (Kornberg et al., 1982; Street, 1973; White, 1988). Legislatures also do not feature prominently in debates regarding the centralization thesis, with those on both the cabinet- and first-minister dominant sides presuming that they are largely irrelevant (Heffernan, 2003; Weller, 1985). As Bernier and colleagues argue in the provincial context, "First, the executive developed an ever-greater capacity to control the legislature and evade or override traditional controls and limits placed on executive behaviour, and, second the Premier's office attained considerable independent capacity and autonomy from the rest of the executive branch" (2005: 248).

Such generalizations, however, mask substantial variations in the relationship between provincial executives and legislatures both over time and between jurisdictions. To measure the presence and extent of centralization across jurisdictions, it is necessary to see the marginalization of provincial legislatures as a distinct process and to explore the means by which it was achieved.

Much of the party discipline and voting unity observed within Westminster legislatures is self-imposed (Docherty, 2005). It should not be surprising that legislators elected under the same party banner would have similar preferences. Legislators also understand that the appearance of party unity can improve their own electoral fortunes. Yet Kam (2009) demonstrates that shared values and selfinterest among legislators from the same party are insufficient to generate the 
voting unity observed within Westminster systems. Instead, parties use a variety of tools to actively maintain cohesion, which Kam combines as the "LEADS" model of party unity: "Loyalty Elicited through Advancement, Discipline, and Socialization" (2009: 15, emphasis in original). Under this model, the prospect of advancement through promotion to executive roles is used to incentivize backbenchers' compliance with party positions: those in the executive have more power and prestige but only those who toe the line can access executive positions. At the same time, the carrot of promotion is balanced with the stick of discipline, with legislators who do break party ranks facing sanctions, such as the removal of executive posts or a loss of central party endorsements in nomination battles. Parties also strive to socialize their legislators so that party unity and loyalty become internalized norms of behaviour that will be followed without ongoing incentives or threats.

Kam (2009) does not engage with the centralization debate directly, but his model generates several predictions for the kinds of institutional changes that would be expected as the process unfolded. Most obviously, centralizing executives have an incentive to increase the number of positions to which backbench members can be promoted. As Kam describes, while the promise of promotion can initially keep members in line, those who languish on the backbench may eventually lose hope that a promotion will come. Creating more executive or quasi-executive positions increases the number of rewards that first ministers can offer to restless backbenchers and improves members' own calculations regarding their odds of promotion. Moreover, increasing the number of members serving in discretionary positions also increases the first minister's ability to enforce discipline by threatening to remove those posts.

The LEADS model further suggests that discipline can be strengthened by developing new avenues for party socialization and especially those that provide backbenchers with the sense that they have a personal stake in the party's success. In this vein, Garner and Letki's (2005) comparative study of rebellion by government MPs under British Labour Prime Minister Tony Blair and Canadian Liberal Prime Minister Jean Chrétien found that Chrétien's more meaningful use of caucus meetings to solicit input from backbenchers helped to reduce the rates of dissent experienced by his government. Similar findings were also obtained by Wilson (2015) in his study of the "ministerial caucus advisory committees" (MCACs) introduced by Canadian Conservative Prime Minister Stephen Harper. The MCACs were bodies of government backbenchers that ministers had to consult before bringing new initiatives before cabinet. Wilson reports that this pre-legislative input, which occurred in addition to the regular caucus meetings, gave backbenchers feelings of influence and ownership over government policies, thereby helping to build party solidarity and reducing dissent.

Based on these observations, we expect that centralizing provincial executives will engage in "executive creep" by either expanding the number of executive or quasi-executive positions to which government backbenchers can be appointed or by increasing backbench involvement in government decision making. Importantly, while strengthening the executive relative to the legislature, both these institutional changes also increase the influence of the party leader vis-à-vis the cabinet. As noted above, Bernier and colleagues (2005) found that larger cabinets tended to be more institutionalized and were easier for first ministers to control. 
Likewise, the incorporation of backbenchers into government decision making reduces cabinet's monopoly on policy formation and potentially gives first ministers greater scope to overrule recalcitrant ministers. And while the creation of quasi-executive roles does not directly reduce the power of cabinet, the new posts expand the range of patronage positions distributed by first ministers, increasing their influence over backbenchers.

\section{Analytical Approach and Existing Research}

To test these expectations for executive creep, we first consider the ratio of the executive to (1) the legislature as a whole and (2) the size of the government caucus. This approach allows us to capture the proportion of private members from the government available to engage in scrutiny and accountability and particularly the executive's capacity to control the overall function of the assembly. However, while the size of the government caucus ultimately depends on voter preferences, both ratios are conditioned by two major variables: legislature size and executive size.

The literature pays considerable attention to the small size of provincial legislatures relative to the federal parliament (Docherty, 2005; White and Levy, 1989). As of April 2017, the latter had 338 members, while the provincial average was 69. Yet rather than being fixed, the size of Canadian legislatures is surprisingly malleable. For instance, six of Saskatchewan's 13 elections from 1967 to 2016 saw changes in the number of seats. Since Confederation the trend for legislature size was initially towards growth, but since the 1990s many have seen reductions (Marland and Dunn, 2017). This was the case for the Newfoundland and Labrador House of Assembly, which grew from 42 to 52 seats between 1975 and 2015, only to plummet to 40 . Manitoba is the only province with no change in legislative size since 1967, and four provincial legislatures (Ontario, New Brunswick, Newfoundland and Labrador, and PEI) were smaller in 2017 than they were half a century earlier.

Turning to the second measure, the growth of provincial executives has attracted concern for decades (Bernier et al., 2005; Dunn, 1995; Dyck, 1996; Lewis, 2015). White (1998) notes that provincial cabinets grew rapidly from the 1940s to the 1990s, jumping from an average of 10.9 to 19 members. He blames the increase on the "representative imperative" of Canadian cabinet design, with premiers expanding membership to achieve representational objectives rooted in geography or racial, linguistic or cultural diversity (White, 2001). However, the average size masks a substantial range, with particular concern being paid to the high executivelegislative ratio of smaller assemblies in the Atlantic provinces (Mackinnon, 1972; Smith, 1988). For instance, PEI's cabinet traditionally makes up a third of the legislature, leading to the argument that "debate and decision-making [in the province] take place, in fact if not in form, in the cabinet rather than in the legislature" (Mackinnon, 1972).

Docherty contends that effective legislatures should ideally "be at least four times the size of the cabinet" (2005: 181). Yet this argument, like those detailed above, ignores the growth of non-cabinet and quasi-executive positions. These include junior executive positions similar to federal parliamentary secretaries, as well as those that bridge the gap between the executive and the legislature, such as 
government whips and caucus chairs. Although lacking the status of cabinet, these positions come with a range of perks, such as additional salary, staff and prestige, and thereby can shape legislators' behaviour (Glenn, 1997). As such, they must be included in any analysis regarding changes in the strength and size of the executive relative to the legislature.

The second test of our expectations for executive creep concerns the incorporation of backbenchers into government decision making. Backbench influence is inherently more challenging to capture given that government caucus meetings are almost universally held in private and since perceptions of members' impact on party decisions are subjective. Thankfully, a more reliable measure of backbench participation can be found by exploring the increasing inclusion of backbenchers on provincial cabinet committees. Dunn describes the appointment of backbenchers to cabinet committees as part of the move toward an "inclusive cabinet" in several provinces (2016: 349). The trend appears to date from the early 1980s when Ontario had a cabinet committee chaired by a minister yet populated by private members (White, 1989). However, the largest change came in the early 1990s when Premier Ralph Klein launched a radical reform of Alberta's cabinet structure (Brownsey, 2005). This included slashing the number of cabinet committees from fifteen to three and appointing backbenchers to each. At the same time, he created a series of standing policy committees that were chaired by backbenchers, with ministers as vice-chairs. Policy committee chairs then attended cabinet to represent their views.

During the 1990s, both Premiers Rae in Ontario and Parizeau in Quebec appointed backbenchers to cabinet committees as well (Dyck, 1996). After winning all but two seats in the BC legislature in 2001, the Campbell government adopted a hybrid cabinet structure inspired by Alberta, with five cabinet committees that included backbenchers, and five government caucus committees vice-chaired by ministers (Ruff, 2005). Upon taking power in 2003, Ontario premier Dalton McGuinty similarly assigned virtually every government backbench member to a cabinet committee (Raney et al., 2013). However, the spread of backbench inclusion on provincial cabinet committees has never before been systematically explored.

\section{Method}

Based on the approach set out above, we explore the extent of executive creep by examining changes in four factors that can influence the level of centralization within a legislature: 1 ) the number of legislative seats, 2) the size of the government caucus, 3) the number of cabinet ministers, and 4) the number of quasi-executive members (that is, parliamentary secretaries, caucus chairs, house leaders and whips). We also consider a fifth issue: the inclusion of backbench members on cabinet committees.

Any count of executive roles is difficult due to the transitory nature of many cabinet and quasi-executive positions as well as the often opaque nature of cabinet committees. This challenge is compounded at the provincial level, where a single individual may hold multiple positions at the same time. A lack of resources at provincial legislatures also means that fewer records are pro-actively disclosed or even maintained, making data gathering a major task in itself. 
We began by contacting the libraries at each provincial assembly to see what information they had on hand. We are grateful for the assistance received but soon found that the information we sought either did not exist or was not kept in a uniform fashion across provinces, forcing us to rely on a range of sources. For the study of cabinet and quasi-executive positions, we used lists of former members maintained by different legislatures (Alberta, Ontario, Quebec, Saskatchewan), data from provincial Hansards and supplementary information from editions of the Canadian Parliamentary Guide. We are also indebted to the legislative librarians in Manitoba, Newfoundland and Labrador, and PEI, and to the Cabinet Secretariat in Saskatchewan which prepared datasets on our behalf. The specific sources used for each province are listed in the online supplementary material.

The resulting dataset captures the variables listed above at the time of dissolution for each legislature in each province beginning in 1968. We then add a snapshot of the provincial legislatures at the time of data collection in May 2017, yielding a sample of 139 legislatures across the 10 provinces, with 9493 individual legislator time-points. This dataset reflects a historical approach that enables us to examine how provincial legislatures and cabinets have changed over time. We adopt 1968 as a starting date to reflect the theoretical dawn of "modern politics" in Canada. ${ }^{2}$ We believe dissolution is the best time to capture data on executive posts as it both reflects a government's "ideal" roster heading into the next election and allows time for any learning curve that incoming administrations may experience following a change in government.

For backbench participation on cabinet committees, Alberta, BC, Ontario, Saskatchewan and Quebec post committee membership online. However, finding data for the other provinces proved more challenging. Therefore, we again turned to a range of sources which are also listed in the online supplementary material. Unfortunately, it proved impossible to acquire reliable information for every jurisdiction for all but the most recent session of each legislature.

\section{Results}

\section{Proliferation of parliamentary secretary style positions}

All provinces except PEI have created parliamentary secretary-style positions at one point or another, albeit with a variety of names: parliamentary secretaries (Alberta, BC), parliamentary assistants (Alberta, Ontario and Quebec), legislative assistants (Alberta, Manitoba), legislative secretaries (New Brunswick and Saskatchewan) and ministerial assistants (Nova Scotia). In Newfoundland and Labrador, there is one parliamentary assistant to the premier and several parliamentary secretaries who support ministers. In keeping with the federal practice, legislators holding these positions are usually tasked with assisting a specific minister but typically are not sworn into the provincial executive council (the provincial equivalent of the federal Privy Council). ${ }^{3}$ Except for a brief period in Alberta described below, this lack of executive council status distinguishes those in provincial parliamentary secretary-style posts from the various "associate minister" roles that have existed within some provincial cabinets. ${ }^{4}$

While provinces established parliamentary secretaries at different times, there were two major waves with distinct outcomes. The first began with Quebec in 
1954, followed by Saskatchewan in 1965, Manitoba and Newfoundland and Labrador in 1970, Ontario in 1972, and BC in 1985 (Glenn, 1997). ${ }^{5}$ Although the number and powers of the positions varied, the first-wave provinces are distinct for the fact that, once created, the positions were used continuously by successive governments of all political stripes. ${ }^{6}$

Second-wave provinces, however, not only created the positions much later but their initial creation was also undone or substantially changed by subsequent administrations. In Alberta, the Progressive Conservative Stelmach government first created nine "parliamentary assistants" in $2008 .^{7}$ They were initially continued under Premier Redford but after the 2012 election were replaced with ten "associate minister" positions. Various Alberta governments had sporadically created associate ministers since the late 1970s but previously no more than three had served at a time. As in other jurisdictions, those holding the positions were also sworn into the executive council and considered part of cabinet. Redford redefined the associate minister roles to resemble the parliamentary assistants they replaced, with the new appointees being sworn into the executive council but explicitly excluded from cabinet, dividing the executive council into two tiers. The change was shortlived, however, with Redford's successor Jim Prentice naming four associate ministers who sat in cabinet. Yet Prentice also made his own innovation by establishing four new "legislative secretary" posts outside of cabinet and the executive council. After taking power in 2015, NDP Premier Rachel Notley discontinued the legislative secretaries and appointed just one associate minister within her cabinet. However, she later appointed two "parliamentary secretaries" in October 2017, bringing the province to four separate types of junior executive positions within a decade.

A similar dynamic can be found in Nova Scotia, where ministerial assistants were first instituted by NDP Premier Darrell Dexter in 2009, but then discontinued by Liberal Premier Stephen McNeil in 2013. However, McNeil re-established the positions after winning re-election in 2017. In New Brunswick, it was the Alward PCs that established legislative secretaries in 2010, only to see them ended by the Liberal Gallant government in 2014.

This tight clustering of the creation and termination of parliamentary secretary positions within the second wave calls for further study. Nonetheless, these examples demonstrate that the use of parliamentary secretaries at the provincial level is subject to the vagaries of first ministerial discretion. There is also no partisan ownership of the parliamentary secretary concept, with parties of all ideological persuasions introducing them, and both NDP and Liberal governments discontinuing them.

\section{Trends in executive size}

To contextualize the data and account for variations in legislative seats and electoral performance, Figure 1 presents the size of provincial executives relative to the size of each legislature, while Figure 2 presents executive size as a proportion of the government caucus. Within each figure we also disaggregate the data to capture both the actual number of cabinet ministers sworn into the executive council in each province (dotted lines), and what we term "CabinetPlus" (solid lines), which includes 


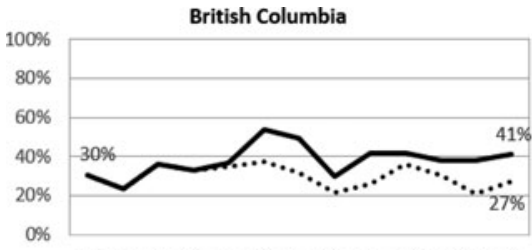

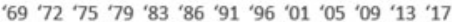
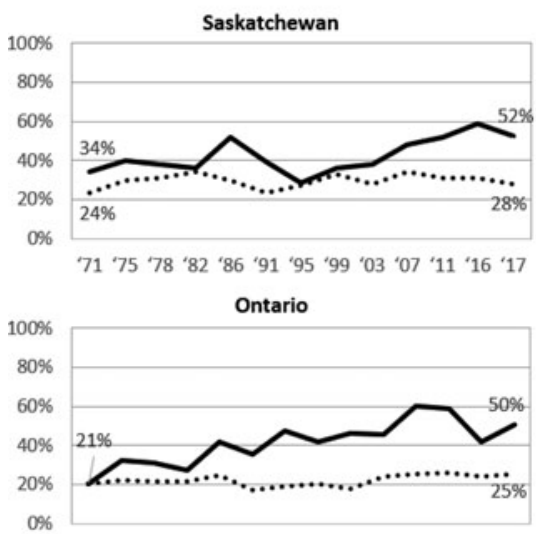

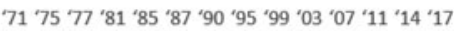
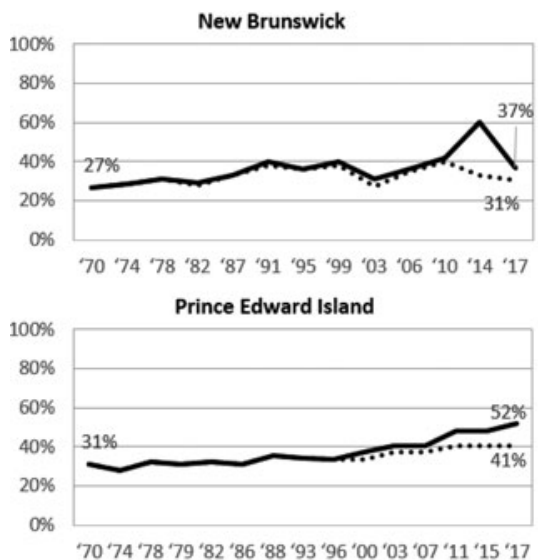

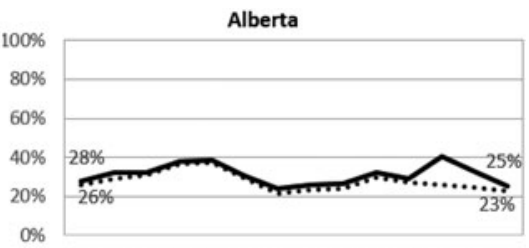

7175 '79 '82 '86 '89 '93 '97 01 '04 '08 '12 '15 '17

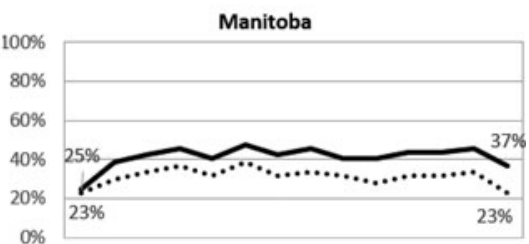

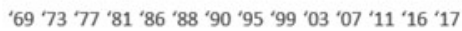

Quebec

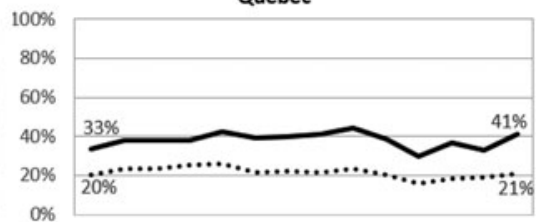

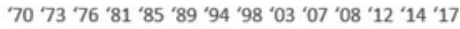

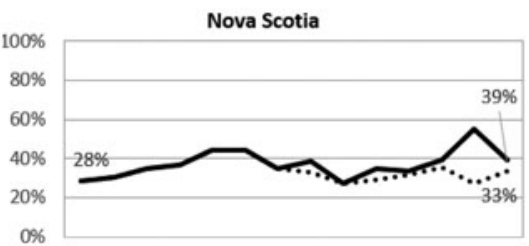

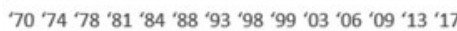

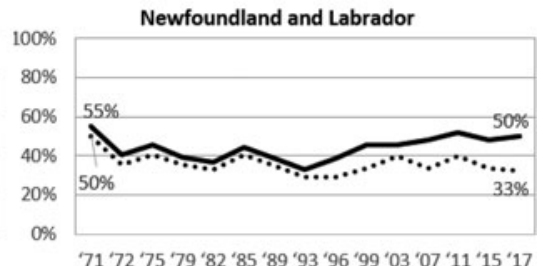

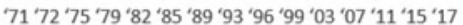

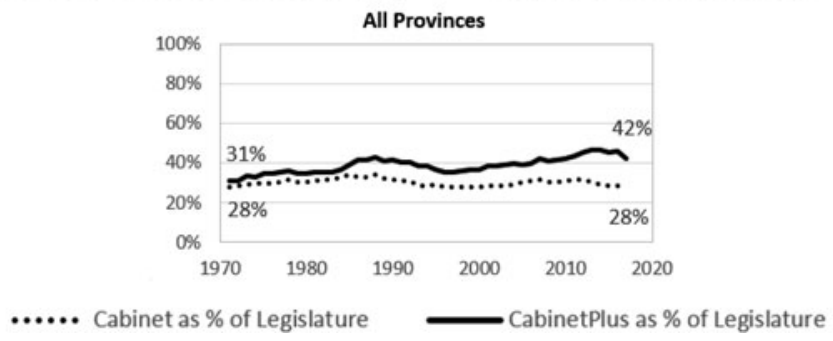

Figure 1. Executive size as a percentage of the legislature. 


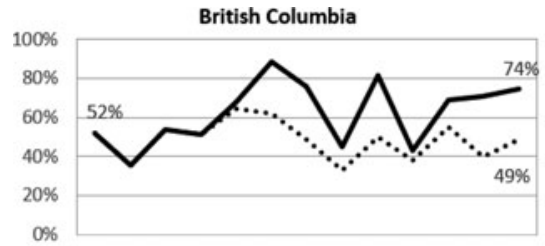

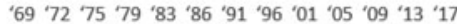

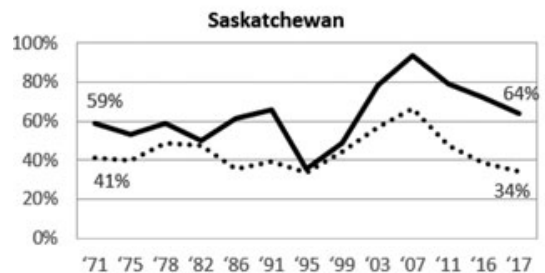

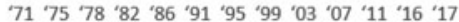

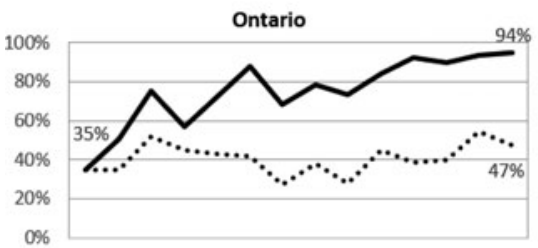

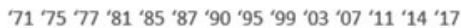
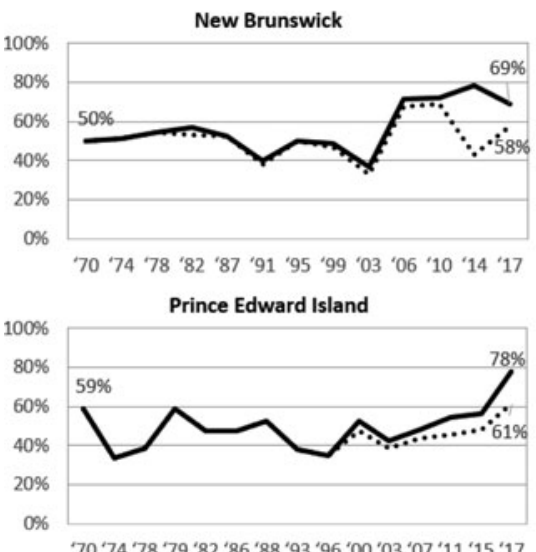

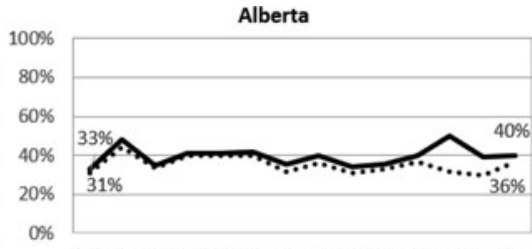

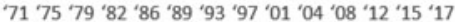

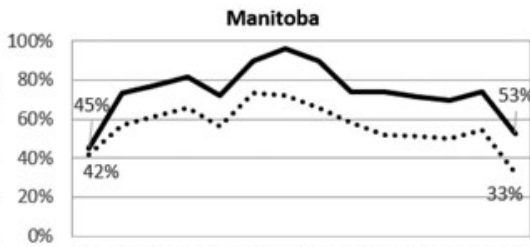

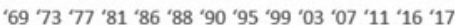

Quebec

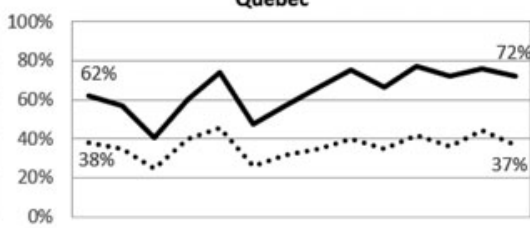

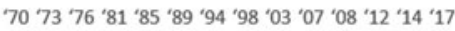

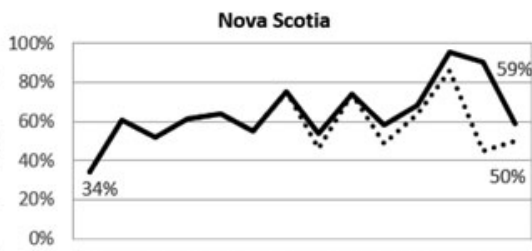

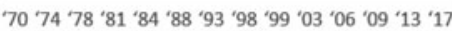

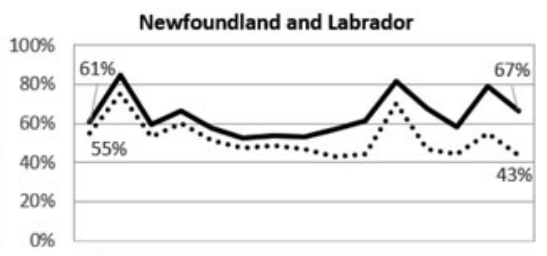

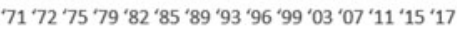

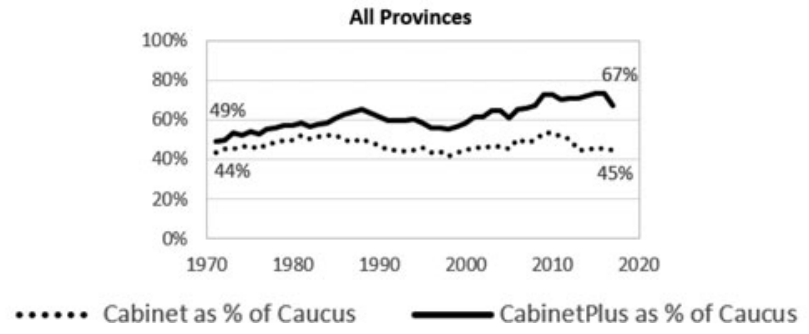

Figure 2. Executive size as a percentage of the government caucus. 
ministers along with other quasi-ministerial or junior executive positions, such as parliamentary secretaries, whips, house leaders and caucus chairs. Both figures also include a chart that averages the results for every province for each year from 1971 to 2017.

As shown in Figure 1, the size of cabinet as a percentage of the legislature has remained stable in most provinces. The same was initially true of the CabinetPlus measure as well, with the two figures being identical or nearly identical in some cases. This lack of differentiation reflects the fact that several jurisdictions either did not record who served in quasi-executive positions such as whip, house leader or caucus chair, or those holding the positions also served in cabinet. For instance, party whips in Ontario once served as ministers without portfolio.

Over the period as a whole, however, Figure 1 shows that the size of CabinetPlus as a percentage of the legislature eventually increased in every province except Alberta and Newfoundland and Labrador. This growth resulted from both the expansion of quasi-executive positions, especially the creation of parliamentary secretary-style posts, and from the gradual differentiation of other quasi-executive positions from the cabinet. Seven of the eight provinces where CabinetPlus rose saw increases of at least 10 percentage points, and by 2017 there were four provinces where CabinetPlus accounted for 50 per cent or more of all legislative seats. Every jurisdiction except Alberta also saw a growth in the gap between the percentage of legislators holding positions in cabinet versus that holding posts in CabinetPlus. In 2017, this was gap especially evident in BC (14 points), Newfoundland and Labrador (17 points), Ontario (25 points), Quebec (20 points), and Saskatchewan (25 points).

Figure 2 reveals considerable variation in the size of cabinet and especially of CabinetPlus as a percentage of the government caucus, both over time and across provinces. All provinces saw a rise in CabinetPlus as a percentage of caucus, including a 59 point rise in Ontario and four others with increases close to 20 points or higher $(B C+22$, New Brunswick +19 , Nova Scotia +25 , and PEI +19$)$. The gap between the proportion of the government caucus in cabinet and the proportion in CabinetPlus also increased in each case, although wide variations remained. For example, in 2017 the Alberta gap was just 4 points, while in Ontario it was nearly 50 points. As of 2017, cabinet made up at least a third of the government caucus in every province, while CabinetPlus consumed more than half of the government caucus in every province but Alberta, and at least two-thirds of the caucus in BC (74\%), New Brunswick (69\%), Newfoundland and Labrador (67\%), Ontario (94\%), PEI (78\%), and Quebec (72\%).

Looking briefly at each province, $\mathrm{BC}$ witnessed clear executive creep over the period once the broader executive is considered. ${ }^{8}$ Moreover, while its cabinet size remained relatively stable in proportionate terms, this trend masks moderate expansion given that the $\mathrm{BC}$ legislature grew from 53 to 87 members during the period. By contrast, the three prairie provinces displayed a different trend, with executive size first peaking between 2010 and 2015 and then declining in recent years. The Alberta results reflect a general restraint in cabinet and CabinetPlus expansion, with increases in legislature size offsetting the growth that did occur. Manitoba's situation is similar, although the constant size of the province's legislature means that executive expansion was even more restrained. Premier Brian Pallister's current 
PC government also substantially reduced the size of cabinet, returning it to the same level as in 1969. The trend in Saskatchewan is more irregular, in part due to the province's uneven experience with legislative secretaries. While NDP administrations were sparing in their use, appointing no more than five at a time, PC and Saskatchewan party governments have appointed 10 on average, contributing to spikes in executive size.

Ontario is Canada's ideal case of executive creep. While the percentage of the legislature serving in cabinet rose only slightly ( +4 points), the mass expansion of quasi-executive posts caused the proportion in CabinetPlus to jump dramatically ( +29 points), such that 50 per cent of all assembly members now have some executive position. Since 2007, Ontario's CabinetPlus has consistently accounted for over 90 per cent of government members, even while it has varied as a proportion of the legislature. These different trajectories reflect the Ontario Liberal party's tendency to appoint nearly all its backbenchers as parliamentary assistants despite substantial changes in the number of seats it holds. This trend suggests that these assistants are not necessary for the functioning of the executive but rather are a tool for caucus management. Indeed, with $94 \%$ of government members in Ontario holding some form of executive role in 2017, the distinction between the government caucus and the executive has all but disappeared.

By comparison, Quebec demonstrates a more gradual instance of executive creep, with small changes in the size of the cabinet as a percentage of the legislature $(+1$ point) and government caucus ( -1 point), matched with somewhat larger increases in the relative size of the CabinetPlus ( +8 points to the legislature; +10 points to the government caucus). ${ }^{9}$ Yet, while Quebec's CabinetPlus makes up a substantial proportion of the legislature (41\% as of 2017), the National Assembly's large size (over 120 seats since 1981) means that in absolute terms it has more backbench and opposition members available for scrutiny than any other jurisdiction.

New Brunswick's cabinet experienced modest growth as a percentage of the legislature ( +4 points) and government caucus $(+8$ points). However, the size of its CabinetPlus increased by more than twice as much on both measures $(+10$ points and +19 points respectively). In Nova Scotia, while both the cabinet and CabinetPlus grew as a proportion of the legislature $(+5$ points and +11 points respectively), the increases were much larger when considered as a proportion of the government caucus $(+16$ points and +25 points respectively). This trend stems from both the gradual expansion of the Nova Scotia executive as well as from the decreasing size of the government caucus, which itself appears to be a consequence of the province's emerging three-party system.

The complete absence of parliamentary secretaries in PEI make its results distinct from all the others. Nonetheless, even though the only additions to the CabinetPlus category were house leaders, caucus chairs or whips not also serving in cabinet, the small size of the legislature (27 members as of 2017) meant that just one or two extra quasi-executive positions could change the overall ratio. As a result, the province still experienced executive creep over the period, with size of the cabinet and CabinetPlus both increasing as a proportion of the legislature $(+10$ points and +21 points respectively). However, PEI's high starting point meant that this executive growth was less evident as a proportion of government caucus than in other provinces. 
Finally, the results for Newfoundland and Labrador echo the recent declines in executive creep observed on the prairies. The size of the cabinet fell as a percentage of both the legislature ( -17 points) and the government caucus ( -12 points). Its CabinetPlus also decreased as a proportion of the legislature ( -5 points), although it rose slightly relative to the government caucus ( +6 points). These reductions in the size of the executive are remarkable given that the Newfoundland and Labrador House of Assembly had fewer members in 2017 than in 1971. However, the province had the country's highest cabinet to legislature ratio (50\%) at the start of the study and even with the decreases it remains in the middle of the pack in terms of the overall extent of executive creep.

\section{Caucus participation on cabinet committees}

Just as the premiers' prerogative over the organization of government and executive leaves an uneven trail of quasi-executive positions, the same is true for cabinet decision-making processes. Table 1 presents statistics for cabinet committee membership among government legislators in each province. The data, current as of the first half of 2017, show that all provinces have cabinet committee systems, ranging from two committees in Nova Scotia to seven in Quebec and Saskatchewan. ${ }^{10}$ All provinces except Alberta, Newfoundland and Labrador, and Quebec also include government members from outside of the cabinet on at least one committee. However, echoing Dunn's observations on the institutionalization of provincial cabinet systems, the pattern of backbench inclusion varies across jurisdictions. Backbenchers sit on the powerful "priorities" committees in BC, Manitoba, Nova Scotia, Ontario and Saskatchewan, yet only in BC and Saskatchewan do they sit on every committee. The proportion of backbenchers with cabinet committee posts also varies from all or nearly all in New Brunswick, Nova Scotia and Ontario to just around 40 per cent for Manitoba and Saskatchewan.

Looking at both executive creep processes together, as of the first half of 2017 all provinces except Alberta had either backbench involvement on cabinet committees, parliamentary secretaries, or both. To fully capture backbenchers' entanglement in the executive, Table 1 also provides the percentage of all government members in each jurisdiction holding a cabinet post, quasi-executive position, or cabinet committee membership. The results show that three, New Brunswick, Nova Scotia, and PEI, have no backbenchers without extra "executive" type roles. BC and Ontario follow closely behind, with 94 and 98 per cent of government members holding some executive role. Manitoba, Newfoundland and Labrador, Quebec and Saskatchewan then fall into a second category, with each having close to 70 per cent of their government caucuses involved in the executive. Alberta is the lone standout, with the only government members serving in the executive being those in cabinet.

At first glance, the decision of Alberta's current NDP government to abandon the previous PC administration's practices of appointing legislative secretaries and including backbenchers on cabinet committees would appear to run counter to the national trend towards executive creep. Yet rather than signal the end of backbench engagement, the changes coincided with the creation of a new caucus advisory committee system like that established by the Harper government at the 
Table 1. Cabinet Committee \& Backbenchers (2017)

Gov. members with exec, quasi

Gov. backbenchers out Gov. backbenchers on at least exec, or cabinet committee

Cabinet committees of total members one cabinet committee post

BC Environmental and Land Use

Legislative Review

$5 / 6$

Priorities and Planning

$1 / 11$

Secure tomorrow

$8 / 18$

Strong economy

Treasury Board

AB Climate Leadership Policy $\quad 0 / 5$

$3 / 10$

Economic Development Policy $\quad 0 / 7$

Legislative Review

Municipal Governance

Social Policy

Treasury Board

SK Crown Investments Corporation of Saskatchewan

Legislation and Regulation Review (LRR)

$19(82 \%)$

$44(94 \%)$

LRR Red Tape Committee

Sub-committee on Public Sector Bargaining

Provincial Land Use

Priorities and Transformational Change

Treasury Board

MB All Aboard Committee ("Poverty Reduction Committee")

Fiscal Responsibility

Healthy Child

Priorities and Planning

Regulatory Accountability

Treasury Board

ON Emergency Management

Health, Education and Social Policy

Jobs and Economic Policy

Legislation and Regulations

Priorities, Delivery and Growth

Treasury Board/Management Board of Cabinet 
Table 1. (Continued.)

NB 2016 Climate Change

Conciliation famille-travail-études

Cabinet committees

Gov. backbenchers out Gov. backbenchers on at least of total members

Gov. members with exec, quasi one cabinet committee

exec, or cabinet committee

(1)

Conseil du trésor

$0(0 \%)$

$51(72 \%)$

Developpement social, éducatif et culturel

$0 / 6$

$0 / 5$

Implantation de la stratégie maritime

Legislation

Priorités et projets stratégiques

Jobs Board

Legislative Instruments and Regulations Board

Policy Board

Priorities Board

$0 / 21$
$0 / 9$

$0 / 7$

$0 / 7$

$0 / 8$

$4 / 7$

$2 / 9$

Treasury Board

$\begin{array}{lr}\text { NS } & \text { Government Priorities and Legislation } \\ 10 / 27\end{array}$

$2 / 9$

$1 / 7$

reasury and Policy Board

Priorities

Treasury Board

NL Economic Policy

Policy and Planning

Routine Matters and Appointments

Social Policy

Treasury Board

$9(90 \%) \quad 25(100 \%)$

$10(100 \%) \quad 27(100 \%)$

$4(67 \%)$

$17(100 \%)$

Treasury Board


federal level (see Wilson, 2015, for more on the federal system). More research is required to explore how this system compares with cabinet committees or the standing policy committees created by the Klein government as a vehicle for backbench input. However, without a formal role in the machinery of government, it is likely that the new caucus committees are not as influential as those they replaced. Notably, in fall 2017 the Alberta NDP did take tentative steps towards restoring the old system by appointing two parliamentary secretaries and adding a backbench member to two cabinet committees.

\section{Discussion and Conclusion}

Executive creep-the growing influence of provincial executives over their backbench members and legislative branches more broadly-is clearly advancing in Canada. Looking first at executive positions, the aggregate data in Figures 1 and 2 showed no overall change in the size of cabinet as a proportion of the legislature since 1971, and just a 1 percentage point increase relative to the government caucus. However, the extent of executive creep became clear once quasi-executive positions were accounted for using the CabinetPlus variable $(+11$ points and +18 points respectively). All provinces saw the size of CabinetPlus increase as a proportion of the government caucus, and eight provinces saw it increase relative to the legislature as well.

Ontario experienced the most dramatic executive growth, with increases in all four variables, including a 60 percentage point rise in CabinetPlus as a percentage of the government caucus. Given that Ontario is Canada's most populous province, this result would appear to suggest a link between executive creep and government size. Yet surprisingly, the only other provinces to experience growth on all measures were New Brunswick, Nova Scotia and PEI, three of the least populous provinces. Even more remarkable is that none of the three had parliamentary secretaries in 2017, with the increases resulting from a mixture of cabinet growth, the expansion of other quasi-executive positions, and-in New Brunswick and PEI-decreases in legislature size.

The other six provinces all saw the size of cabinet decline as a proportion of the legislature, the government caucus, or both. Of these, BC, Manitoba, Quebec, and Saskatchewan still showed clear signs of executive creep, with the size of CabinetPlus as a proportion of the legislature rising by at least 8 percentage points in each case. Only in Alberta and Newfoundland and Labrador did both measures of executive size shrink relative to the legislature. However, the two still saw CabinetPlus rise as a proportion of the government caucus, presenting the potential for increased executive control over backbenchers.

The extent of executive creep becomes even more pronounced when the appointment of government backbenchers to cabinet committees is also considered. Seven provinces have adopted the practice, including five that include backbenchers on their powerful priorities and planning committees. When service on cabinet committees is also considered, there are now five provinces where over 90 per cent of government members hold some form of executive role, and four others where the figure is close to 70 per cent. Only in Alberta is less than 50 per cent of the government caucus now involved in the work of the executive, yet there too a system of caucus advisory committees has been established to channel backbench input to ministers. 
This progression of executive creep at the provincial level in Canada is consistent with our expectations for how centralizing provincial executives would seek to exert control over the legislature. The expansion of executives through the proliferation of quasi-executive and parliamentary secretary-style positions not only weakens the independence of those government members who receive them, but the increased influence, salary and profile they offer also create more political carrots for maintaining discipline among those backbenchers left on the outside. Those serving on cabinet committees lack the prestige and increased compensation of executive or quasi-executive positions, yet the positions still give government backbenchers the opportunity to influence policies before they are made public, making members less likely to engage in scrutiny in the legislature itself. Moreover, the committees can serve to build a sense of inclusion and common identity among government members, strengthening party loyalty.

While serving to reduce the independence of the legislature, both the expansion of executive and quasi-executive positions and the inclusion of backbenchers on cabinet committees are likely to concentrate power in the hands of the first minister rather than cabinet. The size, shape and operation of the executive are prerogatives of the first minister. The creation of executive or quasi-executive positions may require initial legislation, but thereafter appointments are made or revoked solely on first ministerial discretion, as are those to cabinet committees. Overall, the executive creep documented here has increased the premiers' capacity to compel loyalty from government members while reducing ministers' monopoly on policy advice.

Depending on the extent to which these practices have been adopted, some provinces may be entering a new era of legislative-executive relations that further marginalizes the legislature as a site of democratic representation. While private members may be encouraged by their new opportunities to influence policy through quasi-executive positions or cabinet committees, relying on private partisan processes instead of engaging in legislative debates undermines the level of transparency and accountability in provincial politics. In addition, the ability of legislative committees to scrutinize the executive would appear to be weakened if most committee members-possibly including the chair-hold official government positions. However, we must note that our approach does not allow us to directly measure the impact of executive creep or the centralization of power on legislative performance or representation. That would require additional information on legislative outputs, levels of public trust, or other indicators. We hope that our dataset can facilitate such performance measurement by better specifying how the operation of Canadian legislatures has evolved over time.

The timing of executive expansion should also be examined in each case. For instance, while Manitoba experienced limited executive growth overall, there was a ten-year period when 90 per cent or more of the government caucus held positions in the CabinetPlus. The other provinces also experienced sudden spikes in executive size: Alberta (late 1990s), BC (mid-1980s and early 2000s), New Brunswick (mid2000s), Newfoundland and Labrador (early 1970s and early 2000s), Nova Scotia (early 2010s), Ontario (late 1980s), PEI (mid-2010s), Quebec (mid-1980s), and Saskatchewan (mid-2000s). This varied timing suggests that the growth of quasi-executive positions is difficult to predict and their existence can be fleeting. Moreover, the party in government during periods of peak executive creep also varies widely. 
We speculate that the dramatic peaks and valleys in levels of executive size could be the result of three factors: 1) institutional change; 2) ideological beliefs; and 3) individual agendas. Institutional trends, such as reductions in legislature size, have an obvious effect on executive creep. If legislatures shrink while the number of ministerial and quasi-executive posts remains stable, then executive creep will increase. Representational demands and caucus pressures also tend to result in gradual executive growth over a government's tenure. On the ideological front, neoliberal or populist influences can lead premiers from all parties to eliminate executive positions to demonstrate restraint or pursue efficiency. Such commitments can lead governments to cut the size of the legislature as well (Pond, 2005). Lastly, individual factors matter-and the individuals in question are the premiers, who may want to put their own stamp on cabinet and caucus management.

While growing more urgent in recent years, debates on the relationship between governments and legislatures in Canada have been based primarily on anecdote. Drawing on expectations rooted in the literature on party discipline, we examined two aspects of executive creep in Canada's provincial legislatures from 1968 until 2017, demonstrating that government backbenchers are increasingly being drawn into the work of the executive through service in cabinet or quasi-executive posts or through appointment to cabinet committees. Although rooted in the institutional context of Canadian parliamentary democracy, we believe that these measures of executive creep can help to illuminate the extent of centralization present in other jurisdictions as well.

Supplementary material. To view supplementary material for this article, please visit https://doi.org/10. $1017 /$ S0008423918000781

Acknowledgments. The authors would like to thank the journal's editorial team and the anonymous reviewers of our manuscript for their helpful and supportive suggestions. Thomas also acknowledges the generous support of the SSHRC postdoctoral fellowship program which enabled this research. We would like to dedicate this article to the late Christopher Dunn who laid the groundwork for research on the evolution of the Canadian political executive.

\section{Notes}

1 We define government "backbenchers" as those not sworn into the executive council as ministers.

2 We define the modern political era in Canada as exhibiting certain traits in political culture and political institutions, such as a sophisticated media landscape, leader-centred political competitions, and professionalized legislatures and institutionalized executive governance.

3 Prime Minister Paul Martin had federal parliamentary secretaries sworn into the Privy Council during his tenure, but no government before or since has employed the practice.

4 For instance, from 2014 to 2016 Ontario Premier Kathleen Wynne's government included an associate minister of finance who was part of cabinet.

5 Newfoundland and Labrador created the post of parliamentary assistant to the premier in 1970. The province's parliamentary secretaries were established in 1982.

6 Saskatchewan is a partial exception to this trend. The province's NDP governments did not appoint any legislative secretaries from 1980 to 1982 and from 1991 to 2001. However, NDP governments appointed legislative secretaries prior to 1980 and did so again after 2001.

7 MLA Dave King served as the legislative secretary to Premier Peter Lougheed from 1971 to 1976. However, no other MLAs served in a similar role prior to the 2008 creation of parliamentary assistants under Premier Stelmach.

8 The BC data were captured immediately before the 2017 provincial election. 
9 In Quebec, the chief government whip and government caucus chair are part of cabinet and so are not included as backbenchers.

$10 \mathrm{BC}$ data from the Liberal government in place prior to the 2017 election.

\section{References}

Atkinson, Michael M., Daniel Beland, Greogry P. Marchildon, Kathleen McNutt, Peter W.B. Phillips and Ken Rasmussen. 2013. Governance and Public Policy in Canada: A View from the Provinces. Toronto: University of Toronto Press.

Aucoin, Peter, Lori B. Turnbull and Mark D. Jarvis. 2011. Democratizing the Constitution: Reforming Responsible Government. Toronto: E. Montgomery Publications.

Bakvis, Herman. 2001. "Prime Minister and Cabinet in Canada: An autocracy in need of reform?" Journal of Canadian Studies 35 (4): 60-79.

Bernier, Luc, Keith Brownsey and Michael Howlett. 2005. "Conclusion: Executive Institutional Development in Canada's Provinces." In Executive Styles in Canada: Cabinet Structures and Leadership Practices in Canadian Government, ed. Luc Bernier, Keith Brownsey and Michael Howlett. Toronto: University of Toronto Press.

Brownsey, Keith. 2005. "The Post-Institutionalized Cabinet: The Administrative Style of Alberta." In Executive Styles in Canada: Cabinet Structures and Leadership Practices in Canadian Government, ed. Luc Bernier, Keith Brownsey and Michael Howlett. Toronto: University of Toronto Press.

Cooper, Christopher A. 2017. "The Rise of Court Government? Testing the Centralization of Power Thesis with Longitudinal Data from Canada." Parliamentary Affairs 3 (1): 589-610.

Docherty, David. 2005. Legislatures. Vancouver: UBC Press.

Dowding, K. 2013. “The Prime Ministerialisation of the British Prime Minister." Parliamentary Affairs 66 (3): 617-35.

Dunn, Christopher. 1995. The Institutionalized Cabinet: Governing the Western Provinces. Montreal: McGill-Queen's University Press.

Dunn, Christopher. 2016. "Premiers and Cabinets." In Provinces: Canadian Provincial Politics, ed. Christopher Dunn. $3^{\text {rd }}$ ed. Toronto: University of Toronto Press.

Dutil, Patrice. 2017. Prime Ministerial Power in Canada: Its Origins under Macdonald, Laurier, and Borden. Vancouver: UBC Press.

Dyck, Rand. 1996. Provincial Politics in Canada: Towards the Turn of the Century. 3rd ed. Scarborough: Prentice Hall.

Elgie, R. 2011. “Core Executive Studies Two Decades On.” Public Administration 89 (1): 64-77.

Franks, C.E.S. 1987. The Parliament of Canada. Toronto: University of Toronto Press.

Garner, Christopher and Natalia Letki. 2005. "Party Structure and Backbench Dissent in the Canadian and British Parliaments." Canadian Journal of Political Science 38 (2): 463-82.

Glenn, J.E. 1997. “Patronage or Apprenticeship?” In Fleming's Canadian Legislatures, 1997, ed. Robert Fleming and J.E. Glenn. 11th ed. Toronto: University of Toronto Press.

Heffernan, R. 2003. "Prime Ministerial Predominance? Core Executive Politics in the UK." The British Journal of Politics and International Relations 5 (3): 347-72.

Kam, Christopher. 2009. Party Discipline and Parliamentary Politics. New York: Cambridge University Press. Kornberg, Allan, William Mishler and Harold D. Clarke. 1982. Representative Democracy in the Canadian Provinces. Scarborough: Prentice-Hall.

Lewis, J.P. 2013. "Elite Attitudes on the Centralization of Power in Canadian Political Executives: A Survey Former Canadian Provincial and Federal Cabinet Ministers, 2000-2010." Canadian Journal of Political Science 46 (4): 799-819.

Lewis, J.P. 2015. “A Consideration of Cabinet Size." Canadian Parliamentary Review 38 (3): 14-24.

Loat, Alison, and Michael MacMillan. 2014. Tragedy in the Commons: Former Members of Parliament Speak Out About Canada's Failing Democracy. Toronto: Random House.

Mackinnon, Frank. 1972. "Prince Edward Island: Big Engine, Little Body." In Canadian Provincial Politics: The Party Systems of Ten Provinces, ed. Martin Robin. Scarborough: Prentice Hall.

Marland, Alex and Christopher Dunn. 2017. Causes and Consequences of Seat Reductions in Canadian Legislatures. Paper presented at Canadian Political Science Association meetings May 30 to June 1. Ryerson University, Ontario. 
Ostrogorsky, Moisey. 1902. Democracy and the Organization of Political Parties. London: Macmillan.

Page, Kevin. 2015. Unaccountable: Truth and Lies on Parliament Hill. Toronto: Viking.

Pond, David. 2005. "Imposing a neo-liberal theory of representation on the Westminster model: A Canadian case." The Journal of Legislative Studies 11 (2): 170-93.

Poguntke, Thomas, and Paul Webb, eds. 2005. The Presidentialization of Politics: A Comparative Study of Modern Democracies. Oxford: Oxford University Press.

Raney, Tracey, Sasha Tregebov and Gregory J. Inwood. 2013. Democratizing the Ontario Legislature: Change, but Change Enough? Canadian Study of Parliament Group: Studies of Provincial and Territorial Legislatures.

Rhodes, R.A.W. 1995. "From Prime Ministerial Power to Core Executive." In Prime Minister, Cabinet and Core Executive, ed. R.A.W. Rhodes and P. Dunleavy. London: St. Martin's Press.

Ruff, Norman J. 2005. "The West Annex: Executive Structure and Administrative Style in British Columbia." In Executive Styles in Canada: Cabinet Structures and Leadership Practices in Canadian Government, ed. Luc Bernier, Keith Brownsey and Michael Howlett. Toronto: University of Toronto Press.

Russell, Peter H. and Lorne Mitchell Sossin, eds. 2009. Parliamentary democracy in crisis. Toronto: University of Toronto Press.

Savoie, Donald J. 1999. Governing from the Centre: The Concentration of Power in Canadian Politics. Toronto: University of Toronto Press.

Smith, Jennifer. 1988. "Ruling Small Worlds: Political Leadership in Atlantic Canada." In Prime Ministers and Premiers: Political Leadership and Public Policy in Canada, ed. Leslie Pal and David Taras. Scarborough: Prentice-Hall Canada.

Street, D.M. 1973. "The Weakness of Provincial Assemblies." In Provincial Government and Politics: Comparative Essays, ed. Donald Rowat. $2^{\text {nd }}$ ed. Ottawa: Carleton University.

Thomas, Paul G. 2003. "Governing from the centre: Reconceptualizing the role of the PM and Cabinet." Policy Options, December 1, http://policyoptions.irpp.org/magazines/paul-martin/governing-from-the-centre-reconceptualizing-the-role-of-the-pm-and-cabinet/ (May 26, 2017).

Thomas, Paul and Graham White. 2017. "Evaluating Provincial and Territorial Legislatures." In Provinces: Canadian Provincial Politics, ed. Christopher Dunn. Toronto: University of Toronto Press.

Weller, P. 1985. First among Equals: Prime Ministers in Westminster Systems. Sydney: George Allen \& Unwin.

Wheare, K.C. 1963. Legislatures. London: Oxford University Press.

White, Graham. 1988. “Governing from Queen's Park: The Ontario Premiership.” In Prime Ministers and Premiers: Political Leadership and Public Policy in Canada, ed. Leslie Pal and David Taras. Scarborough: Prentice-Hall.

White, Graham. 1989. The Ontario Legislature: A Political Analysis. Toronto: University of Toronto Press.

White, Graham. 1998. "Shorter Measures: The changing ministerial career in Canada." Canadian Public Administration, 41 (3): 369-94.

White, Graham. 2001. Beyond Westminster: The New Machinery of Subnational Government: Adapting the Westminster Model: Provincial and Territorial Cabinets in Canada. Public Money and Management 21 (2): 17-24.

White, Graham. 2005. Cabinets and First Ministers. Vancouver: UBC Press.

White, Graham. 2012. “The 'Centre' of the Democratic Deficit: Power and Influence in Canadian Political Executives." In Imperfect Democracies: The Democratic Deficit in Canada and the United States, ed. Patti Tamara Lenard and Richard Simeon. Vancouver: UBC Press.

White, Graham and Gary Levy. 1989. "Introduction: The comparative analysis of Canadian provincial and territorial legislative assemblies." In Provincial and territorial legislatures in Canada, ed. Gary Levy and Graham White. Toronto: University of Toronto Press.

Wilson, R. Paul. 2015. "Minister's Caucus Advisory Committees under the Harper government: Minister's Caucus Advisory Committees." Canadian Public Administration 58 (2): 227-48.

Young, Walter D. and J. Terence Morley. 1983 "The Premier and the Cabinet." In The Reins of Power: Governing British Columbia, ed. Terry Morley, Norman Ruff, Neil Swainson, Jeremy Wilson and Walter Young. Vancouver: Douglas and McIntyre.

Cite this article: Thomas PEJ, Lewis JP (2019). Executive Creep in Canadian Provincial Legislatures. Canadian Journal of Political Science 52, 363-383. https://doi.org/10.1017/S0008423918000781 